\title{
PSYCHOLOGICAL STUDY OF THEMES IN TONI MORISON'S THE BLUEST EYE THROUGH INFERIORITY COMPLEX
}

\author{
Zanyar Kareem Abdul \\ Department of English, College of Education and Language, \\ University of Charmo, Sulaimany, Iraq \\ E-mail: zanyar.kareem@charmouniversity.org
}

Received: 07 May 2020

Accepted: 08 June 2020

\begin{abstract}
Toni Morrison's The Bluest Eye (1970) is one of the controversial modern American novels. She is a Noble Prize winner whose works are praised for addressing the harsh consequences of racism and colour issue in America. The story is written during 1941, the Great Depression in which a black family suffers from poverty, colour skin, and familial issues. Pecola Breedlove, as the protagonist, suffers from Inferiority Complex in a dysfunctional family whose desire is to have white skin and blue eyes. The inferiority complex theory was taken from Alfred Adler, whose works are significantly backbone in the world of psychology. The aims of this research are to analyse the personality of Pecola through which she searches for an ideal beauty as a black female character in the novel and to demonstrate the impact of racist attitude and incestuous relationship within a family. The research result shows that Pecola's lives provide an example of the pain which results from facing Inferiority Complex on which she never sees herself as a complete image of being. It is somewhat broken and lacks selfesteem through which she was seen as a mad woman in the attic.
\end{abstract}

Keywords: black, sex abuse, beating, inferiority complex, psychology

\section{Introduction}

Toni Morrison is one of the most compelling American writers whose works are seen as the revolutionary spirit, Noble Prize winner. The Bluest Eye (1970) is one of the novels which brought a lot of discussion and close critical attention. Morison again focuses on one black female, Pecola, who longs for having blue eyes. Failure to having so, she suffers, cries, and saddened by her inability to be beautiful like other beautiful girls in the town. Morison's themes go around blackness, patriarchal society, raping and female suffering. She is seen as one of the feminist writers in the American history. She was born in Ohio in 1931, died in 2019. Song of Solomon (1977) and Beloved (1987) are the two major works which positions Morrison in the world of literature.

The Bluest Eye (1970) locates in Lorain, Ohio, and the story is about a young AfricanAmerican lady named Pecola who grows up during the years following the Great Depression. Set in 1941, the novel tells the readers dark skin is a significant issue for her; she is consistently regarded as "ugly." As a result, she suffers inferiority complex, which fuels her desire for the blue eyes she equates with "whiteness." The theory belongs to Alfred Adler, Sigmund Freud's colleague. 

Abdul

\subsection{Literature Review}

Morrison's story categorizes specific themes such as "Patriarchy, female suffering, rape, and black skin," it is thus regarded as one of the pioneering female novelists in the history of America. Many critics have confirmed Morrison is the wave of feminism by herself. The novel was written when she was 39 , was proudly reviewed by Leonard John in The New York Times, stating, " prose so precise, so faithful to speech and so charged with pain and wonder that the novel becomes poetry ... But The Bluest Eye is also history, sociology, folklore, nightmare, and music." (1970) It has to be stated that Morrison's works reflect black women; but did not call herself a feminist as clarified in one of her interviews that she wanted to be free from all the obstacles as much as possible, confirming that "off-putting to some readers, who may feel that I'm involved in writing some kind of feminist tract. I don't subscribe to patriarchy, and I don't think it should be substituted with matriarchy. I think it's a question of equitable access, and opening doors to all sorts of things." (Jaffrey, 1998).

\subsection{Research Method}

Okonjo Ogunyemi claims the novel presents an indirect attack of the values of the white majority through the presentation of these values (354). However, Morrison's novels are analyzed and interpreted from different point of views: applying some theories by which the value of her works deem suffice. The argument is chosen in the research is the Inferiority Complex, which belongs to the Austrian Psychologist, Alfred Adler. Adler's theory is about Individual Psychology, which is a direct connection to the psychology of children, a journey from childhood to adulthood. What is taken to the point is that there is "no gap" left between theory and practice; it is somewhat tightens the unity of personality. On account of the method of approach of Individual Psychology, its doctrines hang together as an organic whole. Because it sees the behavior of individuals as motivated and directed by the unity of personality, whatever Individual Psychology has to say about human behavior reflects the same interrelation that is manifested in the activities of the psyche." (The Education of Children, Adler: 4)

\subsection{Discussion}

Psychonalaysis is always a subject in analyzing a novel, especially Morison's novels. Thus, Adler's inferioty complex is nifty in relation to the analysis. Regarding the construction, applicable to Pecola, related to its unity, i.e., it has goals which are built on objective reality, on the contrary, it is on a subjective vision that the individual takes the facts of life. Each person tries to organize himself/ herself according to his personal view, thinks, decides, and sees according to his judgment whether it is right choice or no. Although Adler takes his examples from his clinical cases, the researcher takes into account of literature. Inferiority Complex is another primary concern in Adler's psychology, which in inevitable and thus becomes a part of human nature. From this, compensations and satisfactions are required to complete the gaps. Definitions and analysis are given further in the following sections related to the novel The Bluest Eyes, and Pecola as a young female protagonist, will be the centreanalysed character. The themes are organized according to the following: skin/Blue eyes, sexual abuse/rape, and finally familial issues.

Alfred Adler brings one example of a boy who faces shuttering and tries to hide, or even having thoughts of committing suicide. This becomes a kind of accurate constitution of his life's pattern. But he still needs to overcome the struggle even though he is in the centre of attention. Pecola is taken as one example that faces the Inferiority Complex through which 
obstacles are found in making proper personality. She longs for having the white skin and bluest eyes, which becomes obsessed with that, and as result she goes through challenges and complexity in not deeming what she wants to achieve. She is marked at the first place stating, "Our house is old, cold, and green. At night a kerosene lamps light on the large room. The others are braced in darkness, peopled by roaches and mice. Adults do not talk to us- they gave us directions. They issues orders without providing information. When we trip and fall down they glance at us; if we cut or bruise ourselves, they ask us are we crazy." (The Bluest Eye, 8)

The very beginning of the novel, Pecola is seen as facing the Inferiority Complex by complaining and attacking neighbours and people around her area. A young girl from a poor who believes her black skin is the barrier and lacking white skin with blue eyes; people see them as nothing except an object. Due to lacking the blue eyes, she suffers psychological malaise and needs to recover it, compensation in Adler's term. This produces negative feelings on her, making her isolated in the community in which she cannot be accepted. Uncontrollably, she uses some harsh words, which are the reflection of the Complex she suffers, such as "nigger, fuck, and crazy". She keeps staring at people who have white, and beautiful white body including the teeth; she cannot help it and thus becomes a gap of her personality. She even envies dolls which "blue-eyed yellow-haired" because they are treasured,

"This is beautiful and if you are on this day "worthy" you may have it. I fingered the face, wondering at the single-stroke eyebrows; picked at the pearly teeth stuck like two piano keys between red bowline lips. Traced the turned-up nose, poked the glassy blue eyeballs, twisted the yellow hair." (The Bluest Eye, 19)

Children, such as Pecola, with this type becomes critical and starts nagging about everything which later becomes some sort of hatred towards others, as Pecola's anger is detected to decide 'to destroy white babe dolls'. Pecola prays for blue eyes and being accepted in her community of African American society. She is not valued for what she is and what has been given. Pecola becomes obsessed with what she longs for; fair complexion and blonde hair with blue eyes are always in her imagination. She sees herself "ugly", and it destroys her both physically and psychologically because it devalues women by proposing all women's price lies in her beauty. She wants to define the word "ugliness", "Long hours she sat looking in the mirror, trying to discover the secret of the ugliness, the ugliness that made her ignored or despised at school, by teachers and classmates alike" (43). Failure to do so, instead, she asks God to make her disappear, vanishing into thin air. The whole community is under the control of beauty by which Pecola cannot identify herself; instead she becomes a prey in it. A community, Morrison criticizes, in which race becomes a nightmare and black girls continuously compares themselves with others such as Shirley Temple. The physical attractiveness is found on the cover of the cup in which Pecola compares herself with the photo, touching the eyes, nose and her skin. The wishes all come out wholeheartedly to cover the Complex according to which she sees herself as nothing except a piece of object on the road.

"But their ugliness was unique. No one could have convinced them that they were not relentlessly and aggressively ugly [...] the rest of the family - Mrs. Breedlove, Sammy Breedlove, and Pecola Breedlove- wore their ugliness, 
put it on, so to speak, although it did not belong to them. The eyes, the small eyes set closely together under narrow foreheads. The low, irregular hairlines, which seemed even more irregular in contrast to the straight, heavy eyebrows which nearly met. Keen but crooked noses, with insolent nostrils. They had high cheekbones, and their ears turned forward. Shapely lips which called attention not to themselves but to the rest of the face. You looked at them and wondered why they were so ugly; you looked closely and could not find the source." (The Bluest Eye, 36-37)

It is seen then Pecola does not see herself as an integral part of her community, she believes that the value of African American culture has diminished. She is left all over and becomes a victim of her community. Adler in Understanding Human Nature (1927) confirms that children have inferiorities may suffer struggles and experience a bitter life. They are always obsessive with themselves then soon will become conscious about their inability to cope with life and their existence, This feeling of inferiority is the driving force, the starting point from which every childish striving originates. It determines how this individual child acquires peace and security in life, it determines the very goal of his existence, and prepares the path along which this goal may be reached." (70) It applies to Pecola when she finds emptiness in her life and existence. Failure to have what she wishes for, she is also raped by his father, Cholly. Leaving Pecola pregnant, her dreams and hopes all fade away. Morrison signifies the seasons artistically concerning the characters such as Spring and Autumn, Pecola's babe dies after a while. She left alone and has to carry her colour, blackness. The feeling of Inferiority brings up insecurity of oneself. Instead, she creates an imaginary picture for herself,

Pretty eye. Pretty blue eyes. Big blue pretty eyes. Run, Jip, runs. Jip runs, Alice runs. Alice has blue eyes. Jerry has blue eyes. Jerry runs. Alice runs. They run with their blue eyes. Four blue eyes. Four pretty blue eyes. Bluesky eyes. Blue-like Mrs. Forrest's blue blouse eyes. Morning-glory-blue-eyes. Alice-and-Jerry- blue-storybook-eyes. (44)

She notes different girls around her neighbourhood, checking every single individual scanning their eyes. She is not yet satisfied, but rather a sharp focus on Mary Jane, little picture on the candy cover who has blonde hair, white skin and blue eyes. She believes that by eating the candy is to have the blue eyes, sort of compensation of the Inferiority Complex. Adler in his Individual Psychology (1925) again focuses on Striving for Superiority in which "selfesteem" and "security" are given under the category, relatively this is what Pecola fails to achieve so; she realizes lacking the two and impossible to compensate it. As a result, she remains as she is and left alone as a victim in the community. Adler reckons that everyone strives for superiority and Pecola is one of the examples in the frame of Adlerian Psychology. Familial issues are also significant in the novel especially in the relationship between Cholly and his wife. Cholly is an irresponsible father who is careless and drunk all the times, his "habitual drunkenness and omeriness, provided them both with the material they needed to make their lives tolerable" (The Bluest Eye 36).

At the beginning of the novel, readers are introduced to the fight that Pauline had with her father, Cholly. She is angry and keeps her father to push his fight away from the house, their fighting "relieves the tiresomeness of poverty" (The Bluest Eye 36). It is a failure 
in creating her being, and it rather creates a crisis and delays any attempts for creating themselves. Pettis notices,

Pauline's aggressiveness would seem to distinguish significantly between her response to violence and Pecola's passivity, but in response to the psychological violence perpetrated on black women by the dominant culture, Pauline, like Pecola, practices passivity rather than resistance and succumbs to a fantasy of reality." (28)

Pecola wants to make herself disappear, fed up from that tension she is in. Pauline is also tired listening to the continuous fight between her parents. No solutions at hand when it comes to avoiding being in that bitter reality, difficult survival. In terms of acceptance, Pauline, like Cholly and Pecola, remain "frozen in a world of being-for-the-other and consequently live a life of shame, alienation, self-hatred, and inevitable destruction". (Samuels and Hudson-Weems "The Damaging Look" 10-11). There is no place for him in the community and also regarded as the dead soul in the family. The dysfunctional family has also affected Pecola's inferiority through which an incomplete personality appears, which includes anger, hatred, and self-pity.

\subsection{Conclusion}

Morrison's harsh message in attaching the white community is undeniable, and it denotes the victims in a way readers become a part of it. The path of self-love and self-creation in identifying themselves become a nightmare. Pecola's non- stop attempts in assuring herself owning white skin, and blue eyes are inevitable. Longing for what she wishes for and her painful images in front of her eyes make her insane at the end of the novel. In The Bluest Eye, Morrison encourages questioning of black society's value where black females are the victims and heartbroken. Pecola's lives provide an example of the pain which results from facing Inferiority Complex on which she never sees herself as a complete image of being. It is somewhat broken and lacks self-esteem through which seen as a madwoman in the attic. In The Bluest Eye, one can see a journey in which self-creation and self-acceptance have lost their ways. Thus, nothing is left except the fact of accepting society's norms.

\section{References}

Adler, Alfred. (1930). Eleanore and Jensen. Tans. The Education of Children. London: Bradford \& Dickens.

Adler, Alfred. (1927) Beran, Wolfe. Trans. Understanding Human Nature. New York: Garden City.

Jaffrey, Zia (February 3, 1998). "The Salon Interview - Toni Morrison". Salon. Retrieved December 20, 2014.

Josephine, Diana , and Aseda Fatima R. (2018). “Inaudible Voice of Pecola in Toni Morrison's Novel The Bluest Eye." 6 (1), 335-33.

Leonard, John (November 13, 1970). "Books of The Times". The New York Times. Archived from the original on November 13, 1970. Retrieved on August 12, 2019.

Mosak, H. Harold, and Maniacci P. Michael. (1999). A Prime of Adlerian Psychology. London: Brunner-Routledge.

Okonjo Ogunyemi, Chinkwenye. (1977) "Order and Disorder in Toni Morrison's The Bluest Eye." 19 (1), 112- 20.

Pettis, Joyce. (1987). "Difficult Survival: Mothers and Daughters in The Bluest Eye." 4 (2), 2629. 
Psychological Study of Themes in Toni Morison's The Bluest Eye Through Inferiority Complex, Zanyar Kareem Abdul

Samuels, Wilfred and Clenora Hudson-Weems. (1990). "The Damaging Look: The Search for Authentic Existence in The Bluest Eye." Boston: Twayne Publishers. 